\title{
ANÁLISE CRÍTICA DE GÊNERO NO ENSINO MÉDIO
}

\section{Ana Clara Sevá*, Ariane Paula Barros*, Camila S. Woloche*, Desirée G. H. Rita*, Anelise S. Scherer, Simone R. Vianna Silva.}

\section{Resumo}

Com base na Análise Crítica de Gênero (ACG), a pesquisa busca mapear, por meio de questionários online semi-estruturados, as práticas de letramento (STREET, 1984) e os diferentes gêneros que as constituem, segundo os discursos de professores do Colégio Técnico de Campinas (COTUCA), a fim de averiguar o espaço que práticas de letramento (crítico) ocupam nos sistemas de atividades da comunidade. Os resultados apontam para a importância das questões dos letramentos críticos na formação docente continuada para a promoção de letramentos críticos também entre o corpo discente.

\section{Palavras-chave: \\ Gêneros discursivos, Prática de letramentos, Ensino de línguas.}

\section{Introdução}

Ao usar a língua/linguagem, podemos atuar no mundo como agentes de mudança social (STREET, 1984). Entendemos que o papel da escola (e do ensino de línguas) está associado, portanto, à formação de cidadãos que promovam a diminuição das desigualdades sociais (FREIRE, 1989). Os documentos que norteiam a Educação Básica (p. ex., BRASIL, 2000; 2006; 2018) enfatizam a cultura científica desde a Educação Básica como importante componente na formação crítica. Tal formação depende de uma educação linguística de qualidade, uma vez que a participação na sociedade se dá por meio do engajamento nos gêneros discursivos que a organizam. Para mapear as práticas de letramento no COTUCA/UNICAMP, analisamos as respostas a questionários de inspiração etnográfica, respondidos por 10 professores. A ACG (MEURER, 2002; BHATIA, 2004; MOTTA-ROTH, 2005; 2008), articulação de pressupostos teórico-metodológicos da Análise Crítica do Discurso (FAIRCLOUGH, 1992), da Sociorretórica (p.ex., BAZERMAN, 2007) e da Linguística Sistêmico-Funcional (HALLIDAY; HASAN, 1989), embasa o estudo em associação às perspectivas dos Letramentos (STREET, 1984) e dos Multiletramentos (NLG, 1996; COPE; KALANTZIS, 2000).

\section{Resultados e Discussão}

Para o mapeamento das práticas constituintes do sistema de atividades (BAZERMAN, 2007) do COTUCA, analisamos as respostas aos questionários em termos de: perfil dos professores, práticas de letramento relevantes e sua avaliação sobre elas. Os procedimentos de análise envolveram, portanto: a) identificação dos gêneros discursivos associados a práticas de letramentos; b) descrição e interpretação dos dados gerados; c) explicação e sistematização dos dados em relação ao contexto social mais amplo.

O primeiro passo foi a realização de um escalonamento das respostas de cada professor ao item "Disciplinas ministradas". Para tal ordenação, a partir das ementas das disciplinas, foram utilizados os marcadores "tecnicista" e "social", sendo o primeiro uma forma de categorização de disciplinas mais voltadas ao campo das exatas e o segundo, ao campo das humanas, como vemos a seguir:

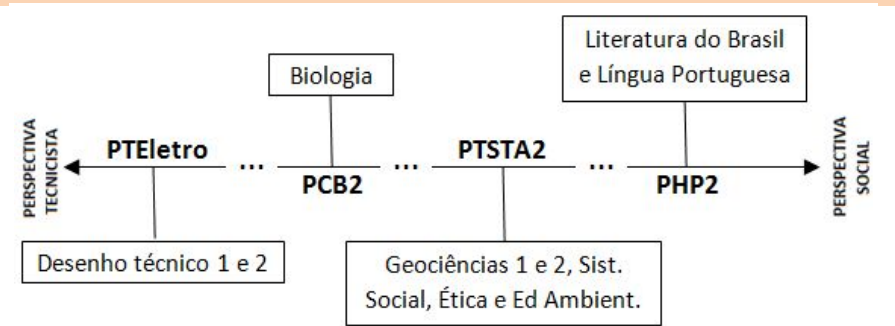

Uma das questões norteadoras da pesquisa, juntamente com seus resultados, é apresentada abaixo. Pudemos observar, ao analisar o total de dez respostas coletadas, que há a predominância de uma perspectiva cognitivista de leitura, considerando-a, ainda, um processo cognitivo, além de fator fundamental para a aquisição de conhecimento (CASTRO, 2007).

Como você avalia o papel da LEITURA na produção de conhecimento e/ou o desenvolvimento de habilidades e competências na sua área de atuação?

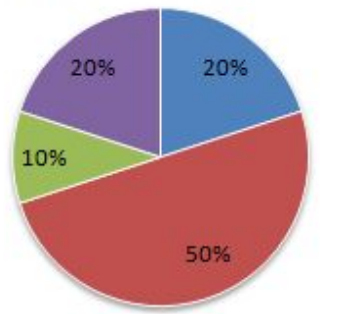

Estruturalista

- Cognitivista

= Interacionalista

= Letramento crítico

\section{Conclusões}

Os resultados apontam para a importância das questões dos letramentos críticos na formação docente continuada para a promoção de letramentos críticos também entre o corpo discente. Identificamos, portanto, a necessidade de uma perspectiva inter/transdisciplinar e colaborativa que permita à comunidade escolar, especialmente professores e alunos, vivenciar a situacionalidade das práticas em projetos de trabalho críticos.

\section{Agradecimentos}

Agradecemos ao PIBIC-EM, pelo financiamento e ao COTUCA, pelo apoio para a execução do projeto.

BAZERMAN, C. Escrita, gênero e interação social. São Paulo: Cortez Editora, 2007

STREET, B. V. Literacy in theory and practice. Cambridge: Cambridge University Press, 1984.

MOTTA-ROTH, D. Análise crítica de gêneros: contribuições para o ensino e a pesquisa de linguagem. D.E.L.T.A., v. 24, n. 2, 2008, pp.341-383. 